\title{
Stroma cell priming in enteric lymphoid organ morphogenesis
}

\section{Manuela Ferreira, Rita G. Domingues and Henrique Veiga-Fernandes*}

Instituto de Medicina Molecular, Faculdade de Medicina de Lisboa, Lisboa, Portugal

\section{Edited by:}

Mark Christopher Coles, University of York, UK

\section{Reviewed by:}

Mark Christopher Coles, University of York, UK

Sanjiv A. Luther, University of Lausanne, Switzerland

Tom Cupedo, Erasmus University Medical Center, Netherlands

*Correspondence:

Henrique Veiga-Fernandes, Instituto de Medicina Molecular, Faculdade de Medicina de Lisboa, Avenida

Professor Egas Moniz, Edifício Egas Moniz, 1649-028 Lisboa, Portugal.

e-mail: jhfernandes@fm.ul.pt

The lymphoid system is equipped with a network of specialized platforms located at strategic sites, which grant strict immune-surveillance and efficient immune responses. The development of these peripheral secondary lymphoid organs (SLO) occurs mainly in utero, while tertiary lymphoid structures can form in adulthood generally in response to persistent infection and inflammation. Regardless of the lymphoid tissue and intrinsic cellular and molecular differences, it is now well established that the recruitment of fully functional lymphoid tissue inducer (LTi) cells to presumptive lymphoid organ sites, and their consequent close and reciprocal interaction with resident stroma cells, are central to SLO formation. In contrast, the nature of events that initially prime resident sessile stroma cells to recruit and retain LTi cells remains poorly understood. Recently, new findings revealed early phases of SLO development putting emphasis on mesenchymal and lymphoid tissue initiator cells. Herein we discuss the main tenets of enteric lymphoid organs genesis and focus in the most recent findings that open new perspectives to the understanding of the early phases of lymphoid morphogenesis.

\section{Keywords: enteric lymphoid organ morphogenesis, stroma cells, LTin cells}

\section{INTRODUCTION}

The lymphoid system possesses highly specialized peripheral organs formed at strategic anatomical sites that constitute threedimensional platforms ensuring efficient immune-surveillance, rapid immune responses and maintenance of protective immunity. Secondary lymphoid organs (SLO), such as lymph nodes (LN) and Peyer's patches (PP), develop during the embryonic life, but can also assemble after birth as it occurs with enteric cryptopatches and isolated lymphoid follicles (Randall et al., 2008; Eberl and Sawa, 2010; van de Pavert and Mebius, 2010; Neyt et al., 2012).

Remarkably, while LN develop at strictly invariable locations along lymphatic vessels, PP develop in variable number and position in the anti-mesenteric side of the mid-intestine (5-12 in mice; Nishikawa et al., 2003). Similarly, cryptopatches appear confined to intestinal lamina propria but they also distribute randomly within the gut wall (Kanamori etal., 1996). Despite these intrinsic differences, SLO development relies on an antigen-independent process where presumptive regions are colonized by lymphoid tissue inducer (LTi) cells that crosstalk with resident mesenchymal cells through lymphotoxin (LT) $\alpha 1 \beta 2$ and LT $\beta$ receptor (LT $\beta$ R) interactions, thus creating a positive feed-back loop that culminates on the anlagen formation.

Although the mechanisms of SLO development have been extensively characterized throughout the years (Randall et al., 2008; van de Pavert and Mebius, 2010; Cupedo, 2011), most studies have been powerless to scrutinize early events preceding LTi cell colonization and clustering. Thus, putative early triggering events preceding LTi cell ingress into lymphoid organ anlagen remain poorly understood (Nishikawa et al., 2003).

\section{GENESIS OF LYMPHOID ORGAN PRIMORDIA:}

\section{THE LTi PARADIGM}

Fetal hematopoietic cells colonize pre-defined sites between embryonic day 9.5 (E9.5) and 16.5 (E16.5) according to the type and location of the prospective lymphoid organ (Rennert et al., 1996; Adachi et al., 1998; Mebius et al., 2001; Yoshida et al., 2001; Veiga-Fernandes et al., 2007; Possot et al., 2011; Tachibana et al., 2011; Cherrier et al., 2012). Hematopoietic cells include

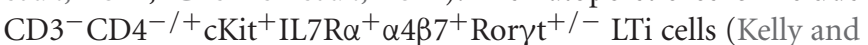
Scollay, 1992; Adachi et al., 1997, 1998; Mebius et al., 1997; Yoshida et al., 1999; Sawa et al., 2010; Possot et al., 2011; Cherrier et al., 2012) and a distinct population of $\mathrm{CD}^{-} \mathrm{CD}^{-}{ }^{-} \mathrm{CKit}^{+} \mathrm{IL} 7 \mathrm{R} \alpha^{-}$ $\mathrm{CD}_{11} \mathrm{c}^{+}$lymphoid tissue initiator (LTin) cells (Hashi et al., 2001; Fukuyama and Kiyono, 2007; Veiga-Fernandes et al., 2007; Patel et al., 2012). PP development depends on LTi and LTin cells, while LN genesis relies on LTi cells although the role of LTin in $\mathrm{LN}$ formation remains elusive. Upon arrival to prospective sites, LTin and LTi cells are believed to establish an interplay with their mesenchymal cell counterparts, lymphoid tissue organizers (LTo) cells, in order to trigger lymphoid organ formation.

The presence of fully functional LTi and LTin cells is necessary for the development of enteric SLO. Absence of LTi cells, as described in mice deficient for Ikaros, Inhibitor of DNA-binding $2(\mathrm{Id} 2)$, retinoic acid-related orphan receptor $\gamma \mathrm{t}(\operatorname{Ror} \gamma \mathrm{t})$, and RUNT-related transcription factor 1 (Runx1)/core-binding factor, beta 2 subunit (Cbfb2), result in PP developmental failure (Wang et al., 1996; Yokota et al., 1999; Sun et al., 2000; Tachibana et al., 2011). Similarly, depletion of LTin cells or deficiency of Ret expression on these cells results in impaired PP formation (Fukuyama and Kiyono, 2007; Veiga-Fernandes et al., 2007). 
Lymphoid tissue inducer cells express the chemokine receptors CXCR5 and CCR7 that specifically bind to the homeostatic chemokines CXCL13 and CCL21/19, respectively. These chemokines create gradients that coordinate LTi cell migration and colonization of presumptive lymphoid organ sites (Forster et al., 1996, 1999; Honda et al., 2001; Luther et al., 2003; Mebius, 2003). In addition, the expression of the adhesion molecules ICAM-1, VCAM-1, and MAdCAM-1 by stroma organizer cells ensures retention of hematopoietic cells through the ligation of the integrin receptors $\alpha 4 \beta 1$ and $\alpha 4 \beta 7$ expressed by LTi and LTin cells surface (Mebius etal., 1996; Hashi et al., 2001; Finke et al., 2002; Veiga-Fernandes et al., 2007). Thus, it is commonly accepted that chemokines and adhesion molecules contribute to a productive and persistent communication between hematopoietic and mesenchymal cells (van de Pavert and Mebius, 2010).

The engagement of LT $\alpha 1 \beta 2$ expressed by LTi cells with stromal cell LT $\beta$ R leads to activation of the classical and alternative NF- $\kappa$ B signaling pathways, which are critical to stroma cell maturation and lymphoid organ development (Weih et al., 1995; Yamada et al., 2000; Alcamo et al., 2001, 2002; Paxian et al., 2002; Yilmaz et al., 2003; Carragher et al., 2004; Lovas et al., 2008). In agreement, mice deficient for LT $\alpha$, LT $\beta$, LT $\beta$ R, or molecular players of the NF- $\kappa$ B signaling pathways fail to develop LN and PP (Rennert et al., 1996, 1997, 1998).

The activation of LT $\beta \mathrm{R}$ results in the maturation of stroma cells, inducing the expression of adhesion molecules MAdCAM1, VCAM-1, and ICAM-1 (Cuff et al., 1999; Dejardin et al., 2002; Yoshida et al., 2002; Ame-Thomas et al., 2007; Vondenhoff et al., 2009a), as well as the homeostatic chemokines CCL19, CCL21, and CXCL13 (Ansel et al., 2000; Luther et al., 2003). In addition, IL-7 and TRANCE induce the expression of LT $\alpha 1 \beta 2$ and generate a positive feed-back loop that sustains a continuous supply of signals between stroma and LTi cells granting maturation of the former (Ansel et al., 2000; Honda et al., 2001; Yoshida et al., 2002; Luther et al., 2003; Mebius, 2003).

\section{MATURATION OF MESENCHYMAL CELLS: THE STROMACENTRIC VIEW}

The general mechanism of SLO development, whereby LTi cells colonize lymphoid organ primordia, is similar among PP and LN anlagen (Yoshida et al., 2002; Randall et al., 2008; van de Pavert and Mebius, 2010; Cupedo, 2011). However, despite the obvious parallels there are also remarkable differences between the morphogenesis of these organs. Examples of such differential processes are provided by IL7/IL7R and TRANCE/TRANCE-R signaling. Thus, while IL7R signal is critical to PP development, as revealed by $I l 7 r^{-/-}$mice, brachial, axillary, and mesenteric LN develop normally in these animals (Adachi et al., 1998; Yoshida et al., 1999; Luther et al., 2003). Furthermore, while in Trance-/and $\mathrm{Traf6}^{-/-}$mice LN development is severely compromised, PP form normally in these mice (Dougall et al., 1999; Naito et al., 1999). Finally, the tyrosine kinase receptor RET also plays a differential role in LN and PP genesis. This is revealed by the absence of $\mathrm{PP}$ in Ret null embryos, which have seemingly normal LN anlagen development (Veiga-Fernandes et al., 2007).

Interestingly, mesenchymal organizer cells from LN and PP also exhibit distinctive genetic features (Yoshida et al., 2002; Cupedo etal., 2004; Okuda etal., 2007). This genetic heterogeneity, suggests that LTo cells may also provide different cues to hematopoietic cells. Nevertheless, it remains unclear whether the acquisition of such divergent genetic profiles are cell autonomous or derived from paracrine cellular interaction with different hematopoietic cell subsets.

The distribution of mesenchymal cells within lymphoid organs differs between PP and LN. In the intestine, stromal cells are distributed throughout the gut tissue that becomes colonized by highly motile hematopoietic cells between day E12.5 and E15.5. At this stage rare VCAM- ${ }^{+}$cells are detected in the gut wall (Adachi et al., 1997). However, by E16.5, VCAM-1 ${ }^{+} / \mathrm{ICAM}-1^{+}$clusters of stroma cells are clearly visible forming PP primordia (Adachi et al., 1997; Yoshida et al., 1999; Hashi et al., 2001; Veiga-Fernandes et al., 2007). Conversely, LN invariably develop within lymph sacs, where ICAM-1 ${ }^{+}$VCAM- ${ }^{+}$mesenchymal stromal cells initially surround endothelial cells and by E16.5 start to invade the endothelium core to form a proper compartment of the anlagen (Okuda et al., 2007). Surprisingly, although lymphatic endothelial cells are essential to the correct formation of LN and lymphatic vasculature, they are dispensable for the initial aggregation of LTi and LTo cells (Cupedo et al., 2004; Vondenhoff et al., 2009b; Benezech et al., 2010).

Interestingly, mounting evidence indicates that LTo cells are very heterogeneous. In PP genesis, $\mathrm{VCAM}-1^{+} / \mathrm{ICAM}-1^{+}$organizer cells express LT $\beta$ R, CCL19, and CXCL13 (Adachi et al., 1997; Yoshida et al., 1999; Hashi et al., 2001; Honda et al., 2001; Veiga-Fernandes et al., 2007), and further analysis revealed that this cell population comprises VCAM- $1^{\text {in }}$ ICAM- 1 in and VCAM$1^{\text {hi }}$ ICAM-1 ${ }^{\text {hi }}$ subpopulations (Okuda et al., 2007). Similarly, these populations were also identified in LN (Cupedo et al., 2004; Okuda et al., 2007; Benezech etal., 2010). The comparison of genetic expression between PP and LN VCAM-1 ${ }^{\text {hi ICAM-1 }}{ }^{\text {hi }}$ cells shows that mesenteric LN LTo cells have surface expression of TRANCE, whereas their PP counterparts lack the expression of this ligand (Cupedo et al., 2004; Okuda et al., 2007). Furthermore, microarray analysis revealed that their genetic signatures are distinct. Mesenteric LN stroma cells express significantly higher levels of cytokines and chemokines such as IL6, IL7, CCL7, CXCL1, and CCL11 (Okuda et al., 2007). Conversely, the homeostatic chemokines CCL21, CCL19, and CXCL13 are more abundant in enteric stroma cells. Interestingly, genes implicated in morphogenesis, such as Meox2, Lhx8, and Prrx1, were significantly higher in mesenteric LN when compared to PP counterparts, yet their functional relevance in lymphoid organogenesis is unclear (Okuda et al., 2007).

In addition to previously described VCAM- $1^{\text {in }}$ ICAM- $1^{\text {in }}$ and VCAM- $1^{\text {hi ICAM- }} 1^{\text {hi }}$ stroma cells, another population of VCAM$1^{\text {neg }}$ ICAM-1 ${ }^{\text {neg }}$, expressing PDGFR $\alpha$ but gp38/podoplanin and VEGFR3 negative was identified in LN (Benezech et al., 2010). Although, VCAM- ${ }^{\text {in }}$ ICAM- $1^{\text {in }}$ and VCAM- $1^{\text {hi }}$ ICAM- $1^{\text {hi }}$ cells have been described in PP, the existence of a VCAM- $1^{\text {neg }}$ ICAM$1^{\text {neg }}$ counterpart remains to be investigated (Cupedo et al., 2004; Okuda et al., 2007). VCAM- $1^{\text {neg }}$ ICAM- $1^{\text {neg }}$ stroma cells express Ccl21 and Tnfrl while VCAM ${ }^{\text {hi }}$ ICAM $^{\text {hi }}$ express the highest levels of Ccl21, Ccl19, Cxcl13, Trance, and Il7, as compared with VCAM- $1^{\text {in }}$ ICAM- 1 in , confirming their greater potential to attract 
LTi (Cupedo etal., 2004; Okuda etal., 2007; Benezech etal., 2010). Interestingly, the treatment of LN with $\alpha$ LT $\beta R$ Ab agonist significantly increased the frequency of VCAM- $1^{\text {hi ICAM- } 1 \text { hi }}$ cells (Benezech et al., 2010). In addition, $L t b r^{-/-}$and $\operatorname{Rorc}(\gamma \mathrm{t})^{-/-}$

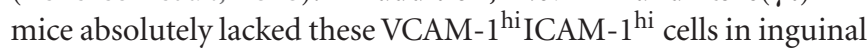
and mesenteric LN (Benezech et al., 2010), thus confirming the implication of LTi cells and the engagement of LT $\beta$ R on the maturation of residential stroma cells. Surprisingly, the emergence of VCAM- ${ }^{\text {in }}$ ICAM- $1^{\text {in }}$ is seemingly normal in the absence of LT $\beta$ R and LTi cells (White et al., 2007; Benezech et al., 2010). These data indicate that while the maturation of VCAM- $1^{\text {in ICAM- }}$ $1^{\text {in }}$ into VCAM-1 ${ }^{\text {hi }}$ ICAM-1 ${ }^{\text {hi }}$ absolutely depends on LT $\beta R$ and LTi cells, the transition from VCAM- ${ }^{10}$ ICAM- $1^{\text {lo }}$ to VCAM$1^{\text {in }}$ ICAM- $1^{\text {in }}$ is LT $\beta$ R and LTi cell independent (Benezech et al., 2010). These conclusions are supported by the fact that the recruitment of LTi cells to lymphoid organ is observed in the absence of LT $\beta$ R signaling (Yoshida et al., 2002; Coles et al., 2006; Vondenhoff et al., 2009a; Benezech et al., 2010), and by the LT $\beta$ Rindependent expression of homeostatic chemokines CCL21 and CXCL13, and the cytokine IL7 (Ansel et al., 2000; Luther et al., 2003; Cupedo et al., 2004; Moyron-Quiroz et al., 2004; Benezech et al., 2010). Finally, while agonist anti-LT $\beta R$ treatment rescues LN development in $L T \alpha^{-/-}$mice, the same treatment in LTi deficient $\operatorname{Rorc}(\gamma t)^{-/-}$mice, fail to promote SLO development (Rennert et al., 1998; Eberl et al., 2004). Altogether, these observations suggest that early LT $\beta$ R-independent events precede LTi cell arrival, initiating a specific genetic expression profile in mesenchymal cells.

In agreement with this hypothesis, it was shown that CXCL13 can be induced by the vitamin A metabolite retinoic acid independently of LT $\alpha 1 \beta 2 /$ LT $\beta$ R signaling (van de Pavert et al., 2009). Interestingly, analysis of mice deficient for RALDH-2, a crucial retinoic acid-synthesizing enzyme, revealed that at E14.5 the majority of LN were absent and CXCL13 expression was undetectable (van de Pavert et al., 2009). Additionally, neuronsexpressing RALDH-1/2 were observed near the LN anlagen, suggesting potential neuronal source of retinoic acid (van de Pavert et al., 2009). Whether this signaling axis has a functional relevance for PP development remains unclear. However, Gdnf and Gfral null embryos fail to develop a myenteric nervous system but still have normal PP development arguing against such hypothesis (Moore et al., 1996; Cacalano et al., 1998; Veiga-Fernandes et al., 2007). Nevertheless, the presence of parasympathetic and/or sympathetic neurons still present in the guts of these mutants, may provide such retinoic acid cues for PP formation. Interestingly, given the role of retinoic acid role in intestinal immune responses, a direct effect of retinoic acid in LTin and/or LTi cell subsets cannot be discarded at this stage (Hall et al., 2011a,b).

\section{THE EARLY PRIMING EVENTS OF ENTERIC SLO: THE LTin CELL REIGN}

In the intestine $\mathrm{CD}^{-} \mathrm{CD} 4^{+} \mathrm{IL} 7 \mathrm{R} \alpha^{+}$LTi cells and VCAM$1^{+} / \mathrm{ICAM}-1^{+}$stromal organizer cells cluster together with $\mathrm{CD}^{-}{ }^{-} \mathrm{CD}^{-}{ }^{-} \mathrm{IL} 7 \mathrm{R} \alpha^{-} \mathrm{cKit}^{+} \mathrm{CD} 11 \mathrm{c}^{+}$cells (Fukuyama and Kiyono, 2007; Veiga-Fernandes etal., 2007). Mice partly depleted of $\mathrm{CD}^{-}{ }^{-} \mathrm{CD} 4^{-} \mathrm{IL}_{7 \mathrm{R}} \alpha^{-} \mathrm{cKit}^{+} \mathrm{CD} 11 \mathrm{c}^{+}$cells have impaired PP development and mice deficient for the receptor tyrosine kinase
RET $\left(\right.$ Ret $\left.^{-/-}\right)$, expressed by this population do not develop PP (Veiga-Fernandes et al., 2007). Thus, CD3- CD4 ${ }^{-}$IL-7R $\alpha^{-}$cKit $^{+}$ $\mathrm{CD}_{11 \mathrm{c}^{+}}$cells were suggested to be involved in early phases of enteric lymphoid tissue formation and were named LTin cells (Fukuyama and Kiyono, 2007; Veiga-Fernandes et al., 2007). Supporting this concept, the RET ligand ARTN induces the formation of ectopic lymphoid structures, and LTin cells are the first hematopoietic cellular entity to cluster together with VCAM-1 expressing stroma cells (Veiga-Fernandes et al., 2007; Patel et al., 2012). Although, LTi cells are scarcely detected at very early phases of enteric organ formation, an extensive accumulation of LTi cells occurs subsequently to LTin cell aggregation (Patel et al., 2012). Interestingly, LTin cells respond unconventionally in trans to all RET ligands, reducing their motility upon contact with mesenchymal cells, in an adhesion-dependent manner (Patel et al., 2012). Furthermore, while Ccl19, Ccl21, and Cxcl13 chemokine expression is not required in this early triggering phase, VCAM-1 blockage results in a profound reduction of cell clustering efficiency, indicating that subsequent up-regulation of VCAM-1 in stroma organizer cells is essential to recruit and retain the first coming LTi cells (Patel et al., 2012). Thus, in opposition to the LTi action mechanism, where chemokines and LT/LT $\beta$ R are key (Hashi etal., 2001; Finke et al., 2002; Luther et al., 2003; Ohl et al., 2003), LTin cells act at very early phases determining early maturation of enteric mesenchymal cells in a RET-dependent, chemokine-independent manner (Patel et al., 2012). Strikingly, in agreement with previous reports in the LN, the initial induction of VCAM-1 expression in enteric stroma cells might not rely on the engagement of LT $\beta R$, since RET ligand stimulation does not up-regulate LT $\beta$ on LTin cells and blockage of LT $\beta$ R signaling does not impair VCAM-1 induction on stromal cells (Patel etal., 2012). Thus, we would like to propose that PP development is a multi-step, multi-cellular process relying on an initial RET-dependent and adhesion-dependent interaction between LTin and mesenchymal cells, which result in stroma cell priming, ultimately leading to efficient LTi cell recruitment (Figure 1). Although, CD11 $\mathrm{c}^{+}$cells have been detected in anlagen LN, Ret $^{-/-}$mice develop peripheral LN (Veiga-Fernandes et al., 2007). Thus it remains unknown whether LTin cells are also implicated in early stroma cell priming of LN. LTin cells have been phenotypically characterized. These cells present some features of dendritic cells, expressing CD11c, CD11b, and MHC class II, but lack DEC205 and express NK1.1 and Gr-1 (VeigaFernandes etal., 2007). Thus, it would be very interesting to understand the precursor-product relationship between LTin cells and other cell lineages. Finally, it would be exceedingly exciting to determine whether LTin and RET responses may also initiate enteric cryptopatches or lymphoid tissue induced in chronic inflammation.

\section{CONCLUDING REMARKS}

Over the last two decades, remarkable findings have consolidated our knowledge on lymphoid organogenesis. Despite differences between diverse lymphoid organs, we can now appreciate that recruitment of fully functional LTi cells is central in LN and PP organogenesis and that, upon their arrival, an intimate and productive cross-talk is established with 


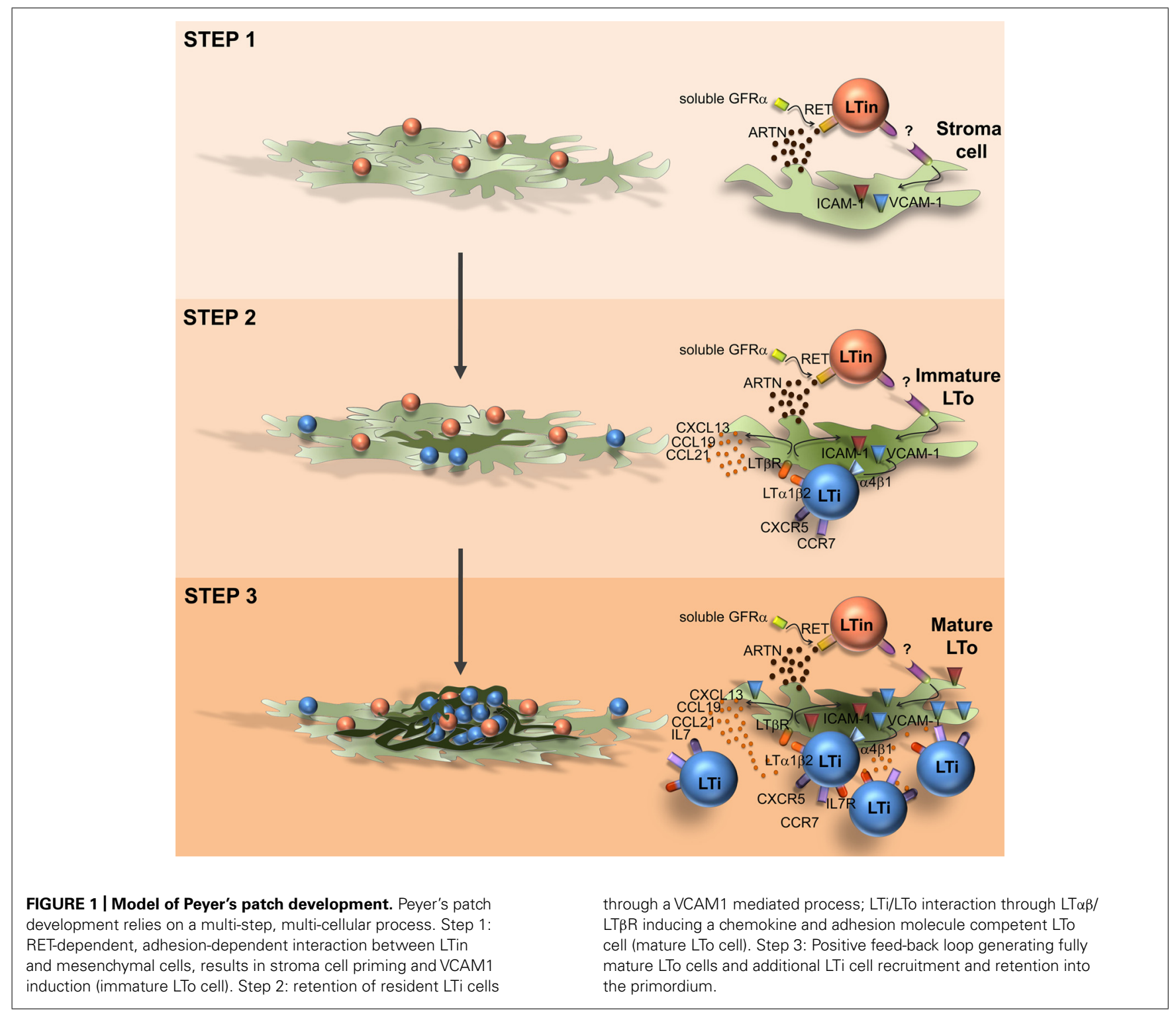

stroma cells. However, new insights have recently shed light on early initiating events that imprint stroma cells to create an attractive milieu for LTi cell recruitment. These findings emphasize a subtle phase, yet crucial to enteric stroma cell maturation, this is the step where LTin cells reign. We foresee the identification of early key players to stroma cell priming in adulthood and inflammatory settings as important challenges in the future.

\section{REFERENCES}

Adachi, S., Yoshida, H., Honda, K., Maki, K., Saijo, K., Ikuta, K., Saito, T., and Nishikawa, S. I. (1998). Essential role of IL-7 receptor alpha in the formation of Peyer's patch anlage. Int. Immunol. 10, 1-6.

Adachi, S., Yoshida, H., Kataoka, H., and Nishikawa, S. (1997). Three distinctive steps in Peyer's patch formation of murine embryo. Int. Immunol. 9, 507514.

Alcamo, E., Hacohen, N., Schulte, L. C., Rennert, P. D., Hynes, R. O., and Baltimore, D. (2002). Requirement for the NF-kappaB family member RelA in the development of secondary lymphoid organs. J. Exp. Med. 195, 233-244.

\section{ACKNOWLEDGMENTS}

Manuela Ferreira was supported by a scholarships from Fundação para a Ciência e Tecnologia, Portugal. Rita G. Domingues was supported by a project grant from Fundação para a Ciência e Tecnologia (PTDC/SAU-MII/104931/2008), Portugal. Henrique Veiga-Fernandes was partly supported by European Molecular Biology Organisation (Project 1648) and European Research Council (Project 207057).

Alcamo, E., Mizgerd, J. P., Horwitz, B. H., Bronson, R., Beg, A. A., Scott, M., Doerschuk, C. M., Hynes, R. O., and Baltimore, D. (2001). Targeted mutation of TNF receptor I rescues the RelAdeficient mouse and reveals a critical role for NF-kappa B in leukocyte recruitment. J. Immunol. 167, 15921600.
Ame-Thomas, P., Maby-El Hajjami, H., Monvoisin, C., Jean, R., Monnier, D., Caulet-Maugendre, S., Guillaudeux, T., Lamy, T., Fest, T., and Tarte, K. (2007). Human mesenchymal stem cells isolated from bone marrow and lymphoid organs support tumor Bcell growth: role of stromal cells in follicular lymphoma pathogenesis. Blood 109, 693-702. 
Ansel, K. M., Ngo, V. N., Hyman, P. L., Luther, S. A., Forster, R., Sedgwick, J. D., Browning, J. L., Lipp, M., and Cyster, J. G. (2000). A chemokinedriven positive feedback loop organizes lymphoid follicles. Nature 406, 309-314.

Benezech, C., White, A., Mader, E., Serre, K., Parnell, S., Pfeffer, K., Ware, C. F., Anderson, G., and Caamano, J. H. (2010). Ontogeny of stromal organizer cells during lymph node development. J. Immunol. 184, 4521-4530.

Cacalano, G., Farinas, I., Wang, L. C., Hagler, K., Forgie, A., Moore, M., Armanini, M., Phillips, H., Ryan, A. M., Reichardt, L. F., Hynes, M., Davies, A., and Rosenthal, A. (1998). GFRalphal is an essential receptor component for GDNF in the developing nervous system and kidney. Neuron 21, 53-62.

Carragher, D., Johal, R., Button, A., White, A., Eliopoulos, A., Jenkinson, E., Anderson, G., and Caamano, J. (2004). A stromaderived defect in NF-kappaB2-/mice causes impaired lymph node development and lymphocyte recruitment. J. Immunol. 173 , 2271-2279.

Cherrier, M., Sawa, S., and Eberl, G. (2012). Notch, Id2, and RORgammat sequentially orchestrate the fetal development of lymphoid tissue inducer cells. J. Exp. Med. 209, 729 740 .

Coles, M. C., Veiga-Fernandes, H., Foster, K. E., Norton, T., Pagakis, S. N., Seddon, B., and Kioussis, D. (2006). Role of T and NK cells and IL7/IL7r interactions during neonatal maturation of lymph nodes. Proc. Natl. Acad. Sci. U.S.A. 103, 13457-13462.

Cuff, C. A., Sacca, R., and Ruddle, N. H. (1999). Differential induction of adhesion molecule and chemokine expression by LTalpha3 and LTalphabeta in inflammation elucidates potential mechanisms of mesenteric and peripheral lymph node development. J. Immunol. 162, 5965-5972.

Cupedo, T. (2011). Human lymph node development: an inflammatory interaction. Immunol. Lett. 138, 4-6.

Cupedo, T., Vondenhoff, M. F., Heeregrave, E. J., De Weerd, A. E., Jansen, W., Jackson, D. G., Kraal, G., and Mebius, R. E. (2004). Presumptive lymph node organizers are differentially represented in developing mesenteric and peripheral nodes. $J$ Immunol. 173, 2968-2975.

Dejardin, E., Droin, N. M., Delhase, M., Haas, E., Cao, Y., Makris, C., Li, Z. W., Karin, M., Ware, C. F., and Green,
D. R. (2002). The lymphotoxinbeta receptor induces different patterns of gene expression via two NF-kappaB pathways. Immunity 17 525-535.

Dougall, W. C., Glaccum, M., Charrier, K., Rohrbach, K., Brasel, K., De Smedt, T., Daro, E., Smith, J., Tometsko, M. E., Maliszewski, C. R., Armstrong, A., Shen, V., Bain, S., Cosman, D., Anderson, D., Morrissey, P. J., Peschon, J. J., and Schuh, J. (1999). RANK is essential for osteoclast and lymph node development. Genes Dev. 13, 2412-2424.

Eberl, G., Marmon, S., Sunshine, M. J., Rennert, P. D., Choi, Y., and Littman, D. R. (2004). An essential function for the nuclear receptor RORgamma(t) in the generation of fetal lymphoid tissue inducer cells. Nat. Immunol. 5 $64-73$

Eberl, G., and Sawa, S. (2010). Opening the crypt: current facts and hypotheses on the function of cryptopatches. Trends Immunol. 31, 50-55.

Finke, D., Acha-Orbea, H., Mattis, A., Lipp, M., and Kraehenbuhl, J. (2002). $\mathrm{CD}^{+} \mathrm{CD}^{-}$cells induce Peyer's patch development: role of alpha4betal integrin activation by CXCR5. Immunity 17, 363-373.

Forster, R., Mattis, A. E., Kremmer, E., Wolf, E., Brem, G., and Lipp, M. (1996). A putative chemokine receptor, BLR1, directs $\mathrm{B}$ cell migration to defined lymphoid organs and specific anatomic compartments of the spleen. Cell 87, 1037-1047.

Forster, R., Schubel, A., Breitfeld, D., Kremmer, E., RennerMuller, I., Wolf, E., and Lipp, M. (1999). CCR7 coordinates the primary immune response by establishing functional microenvironments in secondary lymphoid organs. Cell 99 , 23-33.

Fukuyama, S., and Kiyono, H. (2007). Neuroregulator RET initiates Peyer'spatch tissue genesis. Immunity 26 393-395.

Hall, J. A., Cannons, J. L., Grainger, J. R. Dos Santos, L. M., Hand, T. W., Naik, S., Wohlfert, E. A., Chou, D. B., Oldenhove, G., Robinson, M., Grigg, M. E., Kastenmayer, R., Schwartzberg, P. L., and Belkaid, Y. (2011a). Essential role for retinoic acid in the promotion of CD4(+) $\mathrm{T}$ cell effector responses via retinoic acid receptor alpha. Immunity 34, 435-447.

Hall, J. A., Grainger, J. R., Spencer, S. P., and Belkaid, Y. (2011b). The role of retinoic acid in tolerance and immunity. Immunity 35, 13-22.

Hashi, H., Yoshida, H., Honda K., Fraser, S., Kubo, H., Awane, M., Takabayashi, A., Nakano, H.,
Yamaoka, Y., and Nishikawa, S. (2001). Compartmentalization of Peyer's patch anlagen before lymphocyte entry. J. Immunol. 166, 3702 3709.

Honda, K., Nakano, H., Yoshida, H. Nishikawa, S., Rennert, P., Ikuta, K., Tamechika, M., Yamaguchi, K., Fukumoto, T., Chiba, T., and Nishikawa, S. I. (2001). Molecular basis for hematopoietic/mesenchymal interaction during initiation of Peyer's patch organogenesis. J. Exp. Med. 193, 621-630.

Kanamori, Y., Ishimaru, K., Nanno, M. Maki, K., Ikuta, K., Nariuchi, H., and Ishikawa, H. (1996). Identification of novel lymphoid tissues in murine intestinal mucosa where clusters of c-kit+ IL-7R+ Thy1+ lymphohemopoietic progenitors develop. J. Exp. Med. 184, 1449-1459.

Kelly, K. A., and Scollay, R. (1992) Seeding of neonatal lymph nodes by $\mathrm{T}$ cells and identification of a nove population of $\mathrm{CD}^{-}{ }^{-} \mathrm{CD} 4^{+}$cells. Eur. J. Immunol. 22, 329-334.

Lovas, A., Radke, D., Albrecht, D., Yilmaz, Z. B., Moller, U. Habenicht, A. J., and Weih, F. (2008). Differential RelA- and RelBdependent gene transcription in LT $\beta$ R-stimulated mouse embryonic fibroblasts. BMC Genomics 9, 606 doi: 10.1186/1471-2164-9-606

Luther, S. A., Ansel, K. M., and Cyster, J. G. (2003). Overlapping roles of CXCL13, interleukin 7 receptor alpha, and CCR7 ligands in lymph node development. J. Exp. Med. 197, 1191-1198.

Mebius, R. E. (2003). Organogenesis of lymphoid tissues. Nat. Rev. Immunol. 3, 292-303.

Mebius, R. E., Miyamoto, T., Christensen, J., Domen, J., Cupedo, T., Weissman, I. L., and Akashi, K. (2001). The fetal liver counterpar of adult common lymphoid progenitors gives rise to all lymphoid lineages, $\mathrm{CD} 45^{+} \mathrm{CD} 4{ }^{+} \mathrm{CD} 3^{-}$cells, as well as macrophages. J. Immunol. 166 6593-6601.

Mebius, R. E., Rennert, P., and Weissman, I. L. (1997). Developing lymph nodes collect $\mathrm{CD}^{+}{ }^{+} \mathrm{CD} 3^{-}$LTbeta $^{+}$ cells that can differentiate to APC NK cells, and follicular cells but not $\mathrm{T}$ or $\mathrm{B}$ cells. Immunity 7 , 493-504.

Mebius, R. E., Streeter, P. R., Michie, S., Butcher, E. C., and Weissman, I. L. (1996). A developmental switch in lymphocyte homing receptor and endothelial vascular addressin expression regulate lymphocyte homing and permits $\mathrm{CD} 4^{+} \mathrm{CD} 3^{-}$cells to colonize lymph nodes. Proc. Natl. Acad. Sci. U.S.A. 93, 11019-11024.

Moore, M. W., Klein, R. D., Farinas, I., Sauer, H., Armanini, M., Phillips, H., Reichardt, L. F., Ryan, A. M., Carver-Moore, K., and Rosenthal, A. (1996). Renal and neuronal abnormalities in mice lacking GDNF. Nature 382, 76-79.

Moyron-Quiroz, J. E., Rangel-Moreno, J., Kusser, K., Hartson, L., Sprague, F., Goodrich, S., Woodland, D. L., Lund, F. E., and Randall, T. D. (2004). Role of inducible bronchus associated lymphoid tissue (iBALT) in respiratory immunity. Nat. Med. 10, 927-934.

Naito, A., Azuma, S., Tanaka, S., Miyazaki, T., Takaki, S., Takatsu, K., Nakao, K., Nakamura, K., Katsuki, M., Yamamoto, T., and Inoue, J. (1999). Severe osteopetrosis, defective interleukin-1 signalling and lymph node organogenesis in TRAF6-deficient mice. Genes Cells 4, 353-362.

Neyt, K., Perros, F., Geurtsvankessel, C. H., Hammad, H., and Lambrecht, B. N. (2012). Tertiary lymphoid organs in infection and autoimmunity. Trends Immunol. 33, 297-305.

Nishikawa, S., Honda, K., Vieira, P., and Yoshida, H. (2003). Organogenesis of peripheral lymphoid organs. Immunol. Rev. 195, 72-80.

Ohl, L., Henning, G., Krautwald, S., Lipp, M., Hardtke, S., Bernhardt, G., Pabst, O., and Forster, R. (2003). Cooperating mechanisms of CXCR5 and CCR7 in development and organization of secondary lymphoid organs. J. Exp. Med. 197, 1199-1204.

Okuda, M., Togawa, A., Wada, H., and Nishikawa, S. (2007). Distinct activities of stromal cells involved in the organogenesis of lymph nodes and Peyer's patches. J. Immunol. 179, 804-811.

Patel, Harker, N., Moreira-Santos, L., Ferreira, M., Alden, K., Timmis, J., Foster, K., Garefalaki, A., Pachnis, P., Andrews, P., Enomoto, H., Milbrandt, J., Pachnis, V., Coles, M. C., Kioussis, D., and Veiga-Fernandes, H. (2012). Differential RET signaling pathways drive development of the enteric lymphoid and nervous systems. Sci. Signal. 5, ra55.

Paxian, S., Merkle, H., Riemann, M., Wilda, M., Adler, G., Hameister, H., Liptay, S., Pfeffer, K., and Schmid, R. M. (2002). Abnormal organogenesis of Peyer's patches in mice deficient for NF-kappaB1, NF-kappaB2, and Bcl3. Gastroenterology 122, 1853-1868.

Possot, C., Schmutz, S., Chea, S., Boucontet, L., Louise, A., 
Cumano, A., and Golub, R. (2011). Notch signaling is necessary for adult, but not fetal, development of RORgammat(+) innate lymphoid cells. Nat. Immunol. 12, 949-958.

Randall, T. D., Carragher, D. M., and Rangel-Moreno, J. (2008). Development of secondary lymphoid organs. Annu. Rev. Immunol. 26, 627-650.

Rennert, P. D., Browning, J. L., and Hochman, P. S. (1997). Selective disruption of lymphotoxin ligands reveals a novel set of mucosal lymph nodes and unique effects on lymph node cellular organization. Int. Immunol. 9, 1627-1639.

Rennert, P. D., Browning, J. L., Mebius, R., Mackay, F., and Hochman, P. S. (1996). Surface lymphotoxin alpha/beta complex is required for the development of peripheral lymphoid organs. J. Exp. Med. 184, 1999-2006.

Rennert, P. D., James, D., Mackay, F., Browning, J. L., and Hochman, P. S. (1998). Lymph node genesis is induced by signaling through the lymphotoxin beta receptor. Immunity 9, 71-79.

Sawa, S., Cherrier, M., Lochner, M., Satoh-Takayama, N., Fehling, H. J., Langa, F., Di Santo, J. P., and Eberl, G. (2010). Lineage relationship analysis of RORgammat ${ }^{+}$innate lymphoid cells. Science 330, 665-669.

Sun, Z., Unutmaz, D., Zou, Y. R., Sunshine, M. J., Pierani, A., Brenner-Morton, S., Mebius, R. E., and Littman, D. R. (2000). Requirement for RORgamma in thymocyte survival and lymphoid organ development. Science 288, 2369-2373.

Tachibana, M., Tenno, M., Tezuka, C., Sugiyama, M., Yoshida, H., and Taniuchi, I. (2011). Runx1/Cbfbeta2 complexes are required for lymphoid tissue inducer cell differentiation at two developmental stages. J. Immunol. 186, 1450-1457.

van de Pavert, S. A., and Mebius, R. E. (2010). New insights into the development of lymphoid tissues. Nat. Rev. Immunol. 10, 664-674.

van de Pavert, S. A., Olivier, B. J., Goverse, G., Vondenhoff, M. F., Greuter M., Beke, P., Kusser, K., Hopken, U. E., Lipp, M., Niederreither, K., Blomhoff, R., Sitnik, K., Agace, W. W., Randall, T. D., de Jonge, W. J., and Mebius, R. E. (2009). Chemokine CXCL13 is essential for lymph node initiation and is induced by retinoic acid and neuronal stimulation. Nat. Immunol. 10, 1193-1199.

Veiga-Fernandes, H., Coles, M. C., Foster, K. E., Patel, A., Williams, A. Natarajan, D., Barlow, A., Pachnis, V., and Kioussis, D. (2007). Tyrosine kinase receptor RET is a key regulator of Peyer's patch organogenesis. Nature 446, 547-551.

Vondenhoff, M. F., Greuter, M., Goverse, G., Elewaut, D., Dewint, P., Ware, C. F., Hoorweg, K. Kraal, G., and Mebius, R. E. (2009a). LTbetaR signaling induces cytokine expression and up-regulates lymphangiogenic factors in lymph node anlagen. J. Immunol. 182, 5439-5445.

Vondenhoff, M. F., van de Pavert, S. A., Dillard, M. E., Greuter, M., Goverse, G., Oliver, G., and Mebius, R. E. (2009b). Lymph sacs are not required for the initiation of lymph node formation. Development 136, 29-34.

Wang, J. H., Nichogiannopoulou, A. Wu, L., Sun, L., Sharpe, A. H., Bigby, M., and Georgopoulos, K. (1996). Selective defects in the development of the fetal and adult lymphoid system in mice with an Ikaros null mutation. Immunity 5 , 537-549.

Weih, F., Carrasco, D., Durham, S. K., Barton, D. S., Rizzo, C. A., Ryseck, R. P., Lira, S. A., and Bravo, R. (1995). Multiorgan inflammation and hematopoietic abnormalities in mice with a targeted disruption of RelB, a member of the NF-kappa B/Rel family. Cell 80, 331-340.

White, A., Carragher, D., Parnell, S., Msaki, A., Perkins, N., Lane, P. Jenkinson, E., Anderson, G., and Caamano, J. H. (2007). Lymphotoxin adependent and -independent signals regulate stromal organizer cell homeostasis during lymph node organogenesis. Blood 110, 1950-1959.

Yamada, T., Mitani, T., Yorita, K., Uchida, D., Matsushima, A., Iwamasa, K., Fujita, S., and Matsumoto, M. (2000). Abnormal immune function of hemopoietic cells from alymphoplasia (aly) mice, a natural strain with mutant NF-kappa B-inducing kinase. J. Immunol. 165, 804-812.

Yilmaz, Z. B., Weih, D. S., Sivakumar, V., and Weih, F. (2003). RelB is required for Peyer's patch development: differential regulation of $\mathrm{p} 52-\mathrm{RelB}$ by lymphotoxin and TNF. EMBO J. 22, 121-130.

Yokota, Y., Mansouri, A., Mori, S., Sugawara, S., Adachi, S., Nishikawa, S., and Gruss, P. (1999). Development of peripheral lymphoid organs and natural killer cells depends on the helix-loop-helix inhibitor Id2. Nature 397, 702-706.

Yoshida, H., Honda, K., Shinkura, R., Adachi, S., Nishikawa, S., Maki, K., Ikuta, K., and Nishikawa, S. I. (1999). IL-7 receptor alpha ${ }^{+}$CD3 $(-)$cells in the embryonic intestine induces the organizing center of Peyer's patches. Int. Immunol. 11, 643-655.
Yoshida, H., Kawamoto, H., Santee, S. M., Hashi, H., Honda, K., Nishikawa, S., Ware, C. F., Katsura, Y., and Nishikawa, S. I. (2001). Expression of alpha(4)beta(7) integrin defines a distinct pathway of lymphoid progenitors committed to $\mathrm{T}$ cells, fetal intestinal lymphotoxin producer, $\mathrm{NK}$, and dendritic cells. J. Immunol. 167, 2511-2521.

Yoshida, H., Naito, A., Inoue, J., Satoh, M., Santee-Cooper, S. M., Ware, C. F., Togawa, A., and Nishikawa, S. (2002). Different cytokines induce surface lymphotoxin-alphabeta on IL-7 receptor-alpha cells that differentially engender lymph nodes and Peyer's patches. Immunity 17, 823-833.

Conflict of Interest Statement: The authors declare that the research was conducted in the absence of any commercial or financial relationships that could be construed as a potential conflict of interest.

Received: 06 June 2012; accepted: 07 July 2012; published online: 24 July 2012.

Citation: Ferreira M, Domingues RG and Veiga-Fernandes $H$ (2012) Stroma cell priming in enteric lymphoid organ morphogenesis. Front. Immun. 3:219. doi: 10.3389/fimmu.2012.00219

This article was submitted to Frontiers in Antigen Presenting Cell Biology, a specialty of Frontiers in Immunology. Copyright (c) 2012 Ferreira, Domingues and Veiga-Fernandes. This is an openaccess article distributed under the terms of the Creative Commons Attribution License, which permits use, distribution and reproduction in other forums, provided the original authors and source are credited and subject to any copyright notices concerning any third-party graphics etc. 